\title{
CANINE PANCREATITIS: THE DEVELOPMENT OF THE PANCREATIC INFLAMMATORY CONDITION AND THE CLINICAL-THERAPEUTIC APPROACH
}

\author{
Felipe Gaia de Sousa ${ }^{1}$ \\ Ana Cristina Ribeiro Mendes ${ }^{2}$
}

\begin{abstract}
Pancreatitis, acute or chronic, is a serious disease for dogs, due to its harmful potential and the existence of underdiagnosis. The disease is still the target of studies regarding its pathophysiology and therapeutic mechanisms, because the signs presented by the animals are nonspecific, ranging from mild to severe presentations. It can cause morphofunctional changes in the pancreas and adjacent organs. The diagnosis can be a very difficult task, either due to the variable symptoms and severity of the disease, or the impasses experienced at the time of the complementary exams. Therapeutic management is defined based on the symptoms presented by the animals, ranging from fluid infusion for volume replacement, analgesics, antiemetics, antibiotics, special food, among others.
\end{abstract}

Keywords: Dogs, gastrointestinal disease, pancreatitis, pathophysiology, underdiagnosis.

\section{PANCREATITE CANINA: O DESENVOLVIMENTO DA CONDIÇÃO INFLAMATÓRIA PANCREÁTICA E A ABORDAGEM CLÍNICO-TERAPÊUTICA}

\section{RESUMO}

A pancreatite é uma doença grave para os cães, tanto pelo seu potencial deletério quanto pela existência de subdiagnósticos, e pode ser classificada em aguda ou crônica. A doença ainda é alvo de estudos no que diz respeito a sua patofisiologia e mecanismos terapêuticos, uma vez que os sinais apresentados pelos animais são inespecíficos, variando desde apresentações brandas a graves. Pode causar alteração morfofuncional do pâncreas e órgãos adjacentes. $\mathrm{O}$ diagnóstico pode ser uma tarefa bastante difícil, seja pela sintomatologia variável e gravidade da doença como também pelos impasses vivenciados no momento da realização dos exames complementares. O manejo terapêutico é definido com base na sintomatologia apresentada pelos animais, variando desde a infusão de fluidos para reposição volêmica, analgésicos, antieméticos, antibióticos, alimentação especial, entre outros.

Palavras-chave: Cães, doença gastrointestinal, pancreatite, patofisiologia, subdiagnóstico.

\section{PANCREATITIS CANINA: EL DESARROLLO DE LA CONDICIÓN INFLAMATORIA PANCREÁTICA Y EL ENFOQUE CLÍNICO-TERAPÉUTICO}

\section{RESUMEN}

La pancreatitis, aguda o crónica, es una enfermedad grave para los perros, debido a su potencial nocivo y a la existencia de infradiagnóstico. La enfermedad sigue siendo objeto de estudios en cuanto a su fisiopatología y mecanismos terapéuticos, debido a que los signos que presentan los animales son inespecíficos y van desde presentaciones leves a severas. Puede

\footnotetext{
${ }^{1}$ Pontifícia Universidade Católica de Minas Gerais/PUCMINAS-MG, Correspondência: fgaias@outlook.com

${ }^{2}$ Pontifícia Universidade Católica de Minas Gerais - Betim/MG, Brazil, anacrmpuc@gmail.com
}

Sousa FG, Mendes ACR. Canine pancreatitis: The development of the pancreatic inflammatory condition and the clinical-therapeutic approach. Vet. e Zootec. 2021; v28: 001-011. 
provocar cambios morfofuncionales en el páncreas y órganos adyacentes. El diagnóstico puede ser una tarea muy difícil, ya sea por los síntomas variables y la gravedad de la enfermedad, o por los callejones sin salida experimentados en el momento de los exámenes complementarios. El manejo terapéutico se define en base a los síntomas que presentan los animales, que van desde la infusión de líquidos para reposición de volumen, analgésicos, antieméticos, antibióticos, alimentos especiales, entre otros.

Palabras clave: Perros, enfermedad gastrointestinal, pancreatitis, fisiopatología, infradiagnóstico.

\section{INTRODUCTION}

Currently, the number of physiological digestive changes in dogs increases exponentially. Among the countless gastroenteric problems that affect animals, most of them are liver, pancreatic, stomach and intestinal disorders. Pancreatic changes represent a major cause of important clinical manifestations. Pancreatitis can be a silent disease, since most dogs can manifest symptoms lately. Knowledge about the disease is necessary and becomes the objective of large studies regarding its occurrence, mechanisms of pathophysiology, diagnosis and treatment. In this way, the information obtained provides the veterinary clinician with a broad and well-established view of how the disease is established and the damage it can cause to those affected, in addition to make diagnostic and therapeutic decisions (1).

Animals may show variable signs, depending on the stage and severity of the disease. The diagnosis is configured as a very difficult stage (2), because of symptomatic variability, pancreatitis ends up not being the first suspicion of the veterinarian. The treatment is unique and exclusive for each patient, and there is not a standard treatment for all cases of pancreatitis. The therapeutic options available are the use of fluids for volume replacement, use of antibiotics and anti-inflammatories for inflammation and prevention of secondary infections, analgesics, among others.

The present study aimed to conduct a literature review, based on the descriptors dogs, gastrointestinal disease, pathophysiology and pancreatitis, regarding the characterization and symptomatology of pancreatitis. In addition to showing that the correct diagnosis can improve its prognosis and evolution.

\section{CANINE PANCREATITIS}

Gastrointestinal dysfunctions, in particular, diseases and pancreatic changes are responsible for numerous regional and systemic changes that occur in affected dogs. Thus, the manifestations and clinical signs presented by dogs are quite variable (3) and its can generate a certain degree of distrust regarding their diagnosis. One of the classic signs of pancreatitis is the occurrence of abdominal pain. However, the vast majority of gastroenteric disorders can promote painful manifestations when present. Better perception of behavioral and physiological changes observed in their animals by their owners can increasingly assist in earlier and correct diagnosis of the cause of the changes presented.

\section{DEFINITION, ETIOLOGY AND INCIDENCE}

Pancreatitis can be defined as an inflammatory condition (various patterns of cytokines) $(4,5)$, of an intense and high severity, which affects the pancreatic region and its surroundings. The disease is one of the most common abdominal changes in dogs $(2,3)$. Thus, an animal 
with pancreatitis may present alterations at the level of the specific organ, in addition to lesions in tissues and peripheral organs, such as the stomach and the hepatobiliary system (6). The disease can manifest itself in two ways, acute or chronic $(4,6,7)$, and the definition can be based on chronicity and the degree / number of lesions, in addition to assist in the clinical and therapeutic management of the patient (2). Besides, there is still a more sensitive way to categorize the type of pancreatitis present. It is based on differentiation by histopathological evaluation $(1,4)$, although it may be possible to observe the presence of both forms in a fraction of time (7).

The acute form of the disease is characterized by the establishment of a reversible inflammatory condition $(8,9)$, which can vary from mild to intense, of a quick nature and lasting a few days. However, there is a possibility that even after the correct medication performed, there will be a recurrence of the disease in the patient (6). In addition, some animals may be asymptomatic and have a certain degree of vascular involvement. For animals that have mild acute form and that present only lesions restricted to the main organ, there may be clinical improvement without the use of therapeutic management (6). However, patients who present the disease in an intense way, it is possible to verify the presence of severe pictures of pancreatic involvement, including severe parenchymal damage beyond to systemic repercussion due to injury to the vascular network. Conversely, chronic pancreatitis is present in conditions that have been occurring for a longer time, together with intense organic damage and regional and / or systemic changes such as collagen deposition and morphofunctional destruction of the organ (2). For this form of pancreatitis, the degree of lesions / changes at the pancreatic level and peripheral regions is variable, with the possibility of intense morphofunctional dysfunctions $(7,10)$.

Pancreatitis can affect any animal, however, with greater inclinations for middle-aged dogs (around 5 years old and upwards) (2), also to the elderly and those who are neutered. Regarding sex, studies argue that there is no predisposition for one sex in detriment of the other. However, some research points to higher occurrences in females compared to males, although it can occur in both. Considering the predisposition for breeds, some of them (purebred and crossbreeds) have presented greater occurrences as Miniature Schnauzer, Poodle, Cocker Spaniel, Cavalier King Charles Spaniel, Siberian Husk, Terriers (2), Collies, Boxers, among others $(6,7,10)$. It is noteworthy that the geographical distribution of animals by areas may explain in part the greater occurrence in certain breeds (2). It is an important note noticed by Watson (7) "breed relationships suggest an underlying genetic tendency, mirroring the situation in humans".

Studies show that the disease can be characterized as multicausal, thus, several factors may be associated with the occurrence and progression of the disease $(6,7)$. According to Xenoulis and Steiner (2), it is configured as idiopathic despite the fact that several factors are already cited as possible causes. Watson (7) mentions that the genetic issue and association of causal agents. According to Sousa et al. (6), "among the most frequent causes are the accumulation of adipose tissue and ingestion of fatty diets; deficiencies in the breakdown of fats and lipids (cholesterol and triglycerides), in endocrinopathies (hypothyroidism and diabetes); reduction in pancreatic blood flow due to volume reductions, obstructive and coagulative conditions; misuse and constant dysfunction of corticosteroids; calcium dysfunctions; regional traumas; infectious conditions due to bacteria in the intestinal tract; use of drugs; obstructive pictures and reflux in the pancreatic duct; among others".

\section{PATHOPHYSIOLOGY OF PANCREATITIS}

The way in which pancreatitis occurs is the subject of intense studies due to the lack of a more complete explanation (6). Thus, several hypotheses were raised regarding the

Sousa FG, Mendes ACR. Canine pancreatitis: The development of the pancreatic inflammatory condition and the clinical-therapeutic approach. Vet. e Zootec. 2021; v28: 001-011. 
mechanism of pathogenesis and progression of pancreatic parenchymal lesions. Knowing the process of origin and development of pancreatitis is extremely important, a fact that can corroborate for a greater knowledge about it and about possible regional and / or systemic complications that can be expected. Of these, we can mention the disseminated intravascular coagulation process - DIC (6,7); systemic inflammatory response syndrome - SIRS (11); cardiovascular changes; multiple organ dysfunction syndrome - MODS (7); among others.

The relationship between the pancreas and the hepatobiliary system is partly justified by the amplification of the inflammatory condition (7). Research on the study of pancreatitis in humans has been gaining enormous importance. This fact can be explained due to new investigations of a genetic character that show the occurrence of changes in the enzyme trypsin $(7,12)$. According to Watson (7) the "pathophysiology of this disease is believed to be similar in dogs and cats".

Among the existing hypotheses about the pathogenesis of pancreatitis, the most observed is related to trypsin. Considering a healthy patient, during the digestion process, pancreatic secretion is activated and regulated by some factors. Of these, we can mention the neural perception associated with the desire to eat in addition to the distention of the stomach due to the presence of food. In addition, there is an increase in the release of pancreatic products mediated by the existence of lipid and protein substances at the intestinal level. It is also noteworthy that the secretive and digestive role can be partly controlled by innervations mediated by the vagus nerve, by the local myenteric plexus (Auerbach plexus) and even by hormonal influence (7).

The pancreas is a glandular organ divided into two portions, endocrine and exocrine, whose functions are based on producing insulin / glucagon and pancreatic secretion, respectively. Trypsinogen is the inactive form of trypsin, and it is necessary for enterokinase to play the role of catalyzing the inactive form into active and functional. Trypsin is a protease released by the pancreas and stored in zymogen granules (9) responsible for preventing pancreatic organic self-digestion (7). The storage in these granules is configured as a protective mechanism against the autolytic and inflammatory process (1). Thus, it is suggested that "trypsin is central to the pathogenesis of pancreatitis, and inappropriate early activation of the zymogen trypsinogen to trypsin within the pancreatic acini is the final common pathway triggering pancreatic inflammation". A small portion of the trypsin precursors undergo their own activation process inside the zymogen granules. However, autolysis does not occur due to inactivation mediated by other substances such as molecules auxiliary to segregation, in addition to inhibitors responsible for trypsin secretion - PSTI, also known as inhibitors of Kazal serine protease type-1 (SPINK 1) $(7,12)$.

Studies have found that there may be mutagenic changes both at the level of the trypsin precursor and in the PSTI / SPINK 1 (7). The previous fact may be associated with difficulties in the occurrence of hydrolytic processes, a condition associated with the presence of pancreatitis in human and animal models. Bishop et al. (13) observed the presence of genetic variability that gives rise to SPINK 1. However, Furrow et al. (14) presented findings that the variations observed in SPINK 1 can occur in dogs with or without the disease. Thus, the amplification of the trypsin activation process corroborates so that the protective mechanisms (storage in the zymogen granules) become saturated (7). Therefore, a series of reactions in sequence begin, in which trypsin increasingly activates a greater number of other enzymes (6). Thus, he observes the establishment of an intense pancreatic autolysis, associated with the inflammatory process and areas of lipid necrosis of the pancreatic parenchyma (7). Therefore, there is a severe infectious condition that can be local and/or systemic (1). Due to low elucidation, further studies on the mechanism of occurrence are necessary.

Sousa FG, Mendes ACR. Canine pancreatitis: The development of the pancreatic inflammatory condition and the clinical-therapeutic approach. Vet. e Zootec. 2021; v28: 001-011. 


\section{CLINICAL SIGNS}

The symptoms presented by the affected animals can be characterized in a variety of ways $(6,7)$. Thus, affected dogs may be asymptomatic or have mild, moderate and severe symptoms. The classification will depend on some factors such as the form of the disease, severity, changes in food and water intake, even severe presentations that induce the presence of vomiting and diarrhea (7). In general, the animals present abdominal pain mainly in the epigastric region, changes in appetite and ingestion, anorexia, apathy and prostration, among others $(6,7)$. In moderate cases, vomiting and diarrhea can be seen with some frequency.

According to Watson (7), depending on the severity, "some patients may show the classic so-called praying stance, with the forelegs on the floor and the hind legs standing", although this behavior is not exclusive for pancreatitis. In addition to the signs already mentioned, there are also changes in the physiological process of digestion, production and fecal score with the presence of steatorrhea (14). Despite the onset of the condition, some dogs may have polyphagia, although they have weight loss. Furthermore, animals that in some way have reduced water and / or food intake associated with vomiting and / or diarrhea evolve rapidly to severe cases of hypovolemic dehydration.

It should also be noted that due to the development of asymptomatic pancreatitis, tutors and veterinarians do not observe symptoms that may raise the hypothesis of pancreatitis (6). Thus, the disease is often observed in more evolved and deleterious forms, with a great possibility of systemic involvement, which makes it difficult to stabilize and improve the patient's clinical condition. For intense conditions, it may be possible to observe more important clinical emergencies such as DIC, SIRS, MODS, among others of high magnitude (7).

\section{DIAGNOSIS}

Diagnosing pancreatitis is a task that requires attention, care and great experience. According to information previously mentioned, most of these pictures of pancreatic changes are absent from signs that call the attention of tutors and especially professionals. There is not only a way to diagnose the disease, but strategies that, when combined, provide the clinician with valuable information about the real situation to which the patient is subjected. Given this, it is possible to suspect some diseases that may promote the most observed clinical changes and as the tests are performed, it may be possible to proceed with the exclusion of the differentials and close the picture as pancreatitis. In addition to the data that is obtained from information provided by tutors associated with a complete physical examination, laboratory and imaging tests can contribute to the elucidation of the present condition (16).

Laboratory tests, hematological and biochemical, may show slight and / or significant changes $(6,7)$ as a stress pattern marked by leukocytosis by neutrophilia and lymphopenia (11), in addition to azotemia pre-renal (e.g. dehydration) and changes in total protein values $(6,17)$. Pancreatic inflammation markers such as serum amylase and lipase are enzymes that can be measured to assess pancreatic functioning and, when changes in their values are found in relation to the reference standard for the species, they may indicate the possibility of pancreatitis $(6,7)$. However, they are not very specific markers and with less specificity, since patients with severe conditions can present values within the normal range and other changes such as renal conditions can promote changes in the results (6).

Some tests have already been used to diagnose pancreatitis, such as serum lipase activity and trypsin immunoreactivity, which can be used as a laboratory tool, but are 
considered of low diagnostic value (11). One of the tests that have shown a particular prominence for the diagnosis of pancreatitis is the specific canine pancreatic lipase - Spec cPL $(3,16,18)$ in the commercial serological form, however it presents diagnostic limitations (e.g. chronic forms) (11). Nevertheless, Sousa et al. (6) state that "cPL is produced only in the pancreas and is little affected by extra-pancreatic factors".

The use of imaging tools such as ultrasound (US) and radiography (RX) can also assist in the diagnostic determination of pancreatic lesions $(18,19)$. When compared, US offer more information about the problem than RX, due to its greater sensitivity $(6,7)$. Regardless of which strategy, RX, or US it is necessary that the professional who performs them has experience (18) so that the visualization of the structures and the diagnosis are better defined. According to Sousa et al. (6), "in animals with mild pancreatitis, the organ is uniformly hypoechoic and surrounded by more echogenic fat. While in the case of chronic pancreatitis, it may be increased, with irregular hyperechoic and hypoechoic areas" (18). Other abdominal changes can be seen, but without clinical impact for the animal with pancreatitis.

Upon radiographic examination, although this does not provide valuable information such as US, it may be able to suggest changes in opacity in the epigastric region. In addition, it can offer data related to the morphology and modifications of adjacent structures, whether local and / or systemic, such as the positional deviation of the duodenum and the pylorus; variations in duodenal thickness; hepatic enlargement; mineralized areas; among others (19). New diagnostic tools with computed tomography (CT), scintigraphy, endoscopic retrograde cholangiopancreatography (ERCP) and magnetic resonance imaging (MRI) have been studied to be used for the diagnosis of pancreatitis (7), but still have restricted access to large centers image and research.

\section{TREATMENT}

The treatment of pancreatitis is different and dependent on several factors such as presentation, severity and severity, presence or absence of clinical signs, among others. Thus, the therapeutic regimen is exclusive for each patient, including medications and drugs that are useful for that particular situation, as well as for other diseases. For Sousa et al. (6) "the treatment of pancreatitis does not include defined protocols and the therapeutic management is based on clinical signs that the animal presents. Due to the great magnitude, animals with moderate to severe involvement should be treated in intensive support units due to the number of regional and / or systemic changes present, in addition to being able to rapidly evolve to more severe conditions that constantly threaten their lives.

For those animals that have a history and clinical manifestations of vomiting and diarrhea, it is necessary that volume replacement be performed effectively, since large amounts of volumes are lost during the processes mentioned above (7). Thus, intravenous fluid replacements, usually ringer lactate solutions, enable effective correction of the condition presented by the affected dogs (7). In addition, it can be emphasized that according to Gardner et al. (20) the possibility of changes in pancreatic blood flow occurring is high. Thus, once the pancreatic flow is affected, there may be a chance of blood clotting disorders and vessel permeability (20).

Bhoomagoud et al. (21) argues that the use of crystalloid solutions can improve the hydrogen potential - $\mathrm{pH}$, in addition to preventing the mechanism of activation of more trypsins. The lactated ringer's solution has already been pointed out as an adjuvant in reducing the inflammatory condition when compared to others, as in the case of fluids with salinizing effects (22). However, further research is needed to better prove the evidence. According to Mansfield and Beths (8) "that being said, additional therapy with dextrans, hetastarch or hypertonic saline (at a low bolus dose), may be beneficial in those dogs that have severe

Sousa FG, Mendes ACR. Canine pancreatitis: The development of the pancreatic inflammatory condition and the clinical-therapeutic approach. Vet. e Zootec. 2021; v28: 001-011. 
disease". Mansfield (11) also reports that the use of 7.5\% hypertonic saline can help in the systemic treatment of pancreatitis.

The use of plasma (7) is still the subject of research about its real need (6). In view of this, some authors argue that the administration of plasma can be useful for reducing antiinflammatory conditions, increases in the values of coagulative factors, among other advantages (23). Some authors (24) like to state that the use can be carried out for those patients with severe symptoms, even if there is no new more grounded research that can prove the existence of benefits.

Frequently, the patients present vomiting, of varied origins, which must be controlled in order to avoid greater fluid and electrolyte losses. Therefore, it is recommended the use of antiemetics as dopaminergic inhibitors and those that act on neurokinin-1 (NK1) receptors (7). The use of dopamine infusions is a therapy that has been researched for the longest time (25) and it offers great anti-inflammatory benefits to those affected.

The use of NK-1 blocking drugs, of central and peripheral action, prevent the connection with the receptor and act in the region of substance $\mathrm{P}$ involved with vomiting $(6,26)$. Maropitant is a classic example of an antiemetic drug with favorable results for controlling emesis, although Mansfield and Beths (8) claims that there is no proven evidence. In addition, it may be possible to associate with the former, those who are serotonin - 5HT agonists and antagonists such as ondansetron (8). Mansfield and Beths (8) points out that "even dogs with pancreatitis that are not showing overt signs of nausea or vomiting should be treated with an anti-emetic, especially in the early stages to encourage voluntary eating".

The control of gastric acidity is necessary due to intense vomiting and reduced intake, in addition to the presence of ulcerations, but it must be done rationally (27). Thus, it is already clarified by Williams (28) that by performing a decrease in acidic products at the stomach level, it can promote changes in the amount of pancreatic secretion that is released. However, according to Mansfield and Beths (8) there is no evidence that the use of such drugs can contribute to the treatment of pancreatitis. Sousa et al. (6) point out for cases in which the presence of ulcers is found, and use of ranitidine and omeprazole can offer great advantages.

For cases in which there are signs of infection or bacterial translocation, the use of antibiotics can be of great value, especially those that act against gram-negative bacteria and permeability in pancreatic parenchyma. Bacterial translocation can be observed when there is evidence that intestinal health is compromised with changes in the fecal score and color, in addition to changes in the process of food / water intake. However, the decision to use should be well thought out and indicated, therefore avoiding bacterial resistance (8).

The use of corticosteroids to treat pancreatitis is still the subject of major studies (8). According to Sun et al. (29), corticosteroids have numerous functions, among which we can mention the decrease in inflammatory precursors. According to Okanish et al. (3) "glucocorticoids are known to counteract nearly all pathways of inflammation". In view of the existence of studies that approve or disapprove the use, Okanish et al. (3) conducted a study to evaluate the use of prednisolone in dogs with / without pancreatitis.

According to the research, the carrier dogs are classified on a scale (0-3) which considered 5 variables (weakness / lethargy; anorexia; vomiting; diarrhea; abdominal pain). Of the 86 dogs admitted to hospital, 65 of these were included in the survey and the rest discarded due to the presence of changes that could alter the results (3). Among the tests performed at the beginning and after treatment with prednisolone, they found that levels of Creactive protein and mortality rates after 1 month from the end of treatment were lower in the group treated with corticosteroids (3). In view of the results obtained, they concluded that prednisolone can early improve the clinical signs presented and reduce the values of protein $\mathrm{C}$ (3).

Sousa FG, Mendes ACR. Canine pancreatitis: The development of the pancreatic inflammatory condition and the clinical-therapeutic approach. Vet. e Zootec. 2021; v28: 001-011. 
Normally, animals with pancreatitis will experience pain and can be medicated with painkillers. According to Mansfield and Beths (8), "pain is likely to be mediated as a result of local effects whereby the inflamed and enlarged pancreas itself causes pain, or by subsequent amplification of visceral pain". Thus, pain can be graded from absent to severe, and medications should be used depending on the severity of the painful process. Therefore, some therapies can be used for pain control such as multimodal (7). The drugs most used to control pain in pancreatitis are better described by Mansfield and Beths (8) and Watson (7), including the recommended doses, indications and possible adverse effects.

Nurturing a patient with pancreatitis can be a task that requires attention, especially due to the intense loss of weight and nutrients for severe conditions. Thus, some researchers (28) argued that it was necessary for the organ to go through a rest stage due to the possibility that pancreatic products could further incite the inflammatory condition. However, Niederau et al. (30) observed that the opposite occurred; the pancreatic secretion went through a decrease during the pathological process.

Currently, it is known that the organ can collaborate with pancreatitis if there is no supply of adequate nutrients for body replacement (31). For cases of food restriction, it may be possible to incite the occurrence of an atrophic mechanism of intestinal villi, which further reduces the uptake and absorption of nutrients. Thus, several studies demonstrate the importance and advantages of adequate nutrition in quantity and quality (32-36). Sousa et al. (6) still emphasize that "enteral nutrition can increase antioxidant activity and reduce the acute phase response and the magnitude of the inflammatory response".

Complications resulting from pancreatitis with SIRS and DIC should be evaluated with great caution, treated in the best possible way and always with patients under constant monitoring by the responsible veterinary team. In humans, necrosectomy surgeries can and are performed (6), however, the application to the veterinary area is still restricted to large reference centers in pancreatic research. The prognosis of those affected is variable and depends on some factors such as the presence of symptoms, the institution of treatment and the patient's response to the medications used.

\section{FINAL CONSIDERATIONS}

Canine pancreatitis is a disease of great importance in the clinical routine. Given the above, it is increasingly clear that pancreatitis promotes serious local and / or systemic changes in its patients. Thus, the increasingly detailed knowledge about the pathogenesis of pancreatitis, can corroborate for a better and faster diagnosis. Once clinical signs are detected in a timely manner, the animal will be better assisted with better responses to therapy, which must be specific for each affected animal, meeting the required needs. Once the animals are sent to treatment centers with necessary support and constant monitoring, the chances of survival increase and mortality rates decrease. Further studies are needed to further understand pacreatitis and its consequences for animals.

\section{REFERENCES}

1. Watson PJ. Pancreatitis in dogs and cats: definitions and pathophysiology. J Small Anim Pract. 2015;56(1):3-12. doi: https://doi.org/10.1111/jsap.12293.

2. Xenoulis PG, Steiner JM. Lipid metabolism and hyperlipidemia in dogs. Vet J. 2010;183(1):12-21. doi: https://doi.org/10.1016/j.tvj1.2008.10.011.

Sousa FG, Mendes ACR. Canine pancreatitis: The development of the pancreatic inflammatory condition and the clinical-therapeutic approach. Vet. e Zootec. 2021; v28: 001-011. 
3. Okanishi H, Nagata T, Nakane S, Watari T. Comparison of initial treatment with and without corticosteroids for suspected acute pancreatitis in dogs. J Small Anim Pract. 2019;60(5):298-304. doi: https://doi.org/10.1111/jsap.12994.

4. Zhan X, Wang F, Bi Y, Ji B. Animal models of gastrointestinal and liver diseases. Animal models of acute and chronic pancreatitis. Am J Physiol Gastrointest Liver Physiol. 2016;311(3):343-55. doi: https://doi.org/10.1152/ajpgi.00372.2015.

5. Choi S-W, Kim Y-H, Kang MS, Jeong Y, Ahn J-O, Choi JH, et al. Serum concentration of inflammatory cytokines in dogs with suspected acute pancreatitis. Vet Sci. 2021;8(3):51. doi: https://doi.org/10.3390/vetsci8030051.

6. Sousa FG, Rabelo AL, Rodrigues AK, Silva DET, Diniz GHS, Nunes ISS, et al. Canine pancreatitis: the danger in the routine of veterinarians: review. Pubvet. 2021;15(3):1-9. doi: https://doi.org/10.31533/pubvet.v15n03a769.1-9.

7. Watson PJ. Hepatobiliary and exocrine pancreatic disorders. In: Nelson RW, Guillermo Couto C, editors. Small animal internal practice. 6th ed. St. Louis: Elsevier; 2020. p. 518648.

8. Mansfield C, Beths T. Management of acute pancreatitis in dogs: a critical appraisal with focus on feeding and analgesia. J Small Anim Pract. 2015;56(1):27-39. doi: https://doi.org/10.1111/jsap.12296.

9. Forman MA, Steiner JM, Jane Armstrong P, Camus MS, Gaschen L, Hill SL, et al. ACVIM consensus statement on pancreatitis in cats. J Vet Intern Med. 2021;35(2):70323. doi: https://doi.org/10.1111/jvim.16053.

10. Birchard SJ, Sherding RG. Manual Saunders: clínica de pequenos animais. 3a ed. São Paulo: Roca; 2008.

11. Mansfield C. Pancreatitis in dog. In: Bruyette D, editor. Clinical small animal internal medicine. 2nd ed. Hoboken: John Wiley \& Sons; 2020. p.591-600.

12. Suzuki M, Minowa K, Nakano S, Isayama H, Shimizu T. Genetic abnormalities in pancreatitis: an update on diagnosis, clinical features, and treatment. Diagnostics. 2021;11(1):31. doi: https://doi.org/10.3390/diagnostics11010031.

13. Bishop MA, Xenoulis PG, Levinski MD, Suchodolski JS, Steiner JM. Identification of variants of the SPINK1 gene and their association with pancreatitis in Miniature Schnauzers. Am J Vet Res. 2010;71(5):527-33. doi: https://doi.org/10.2460/ajvr.71.5.527.

14. Furrow E, Armstrong PJ, Patterson EE. High prevalence of the c.74A $>$ C SPINK1 variant in Miniature and Standard Schnauzers. J Vet Intern Med. 2012;26(6):1295-9. doi: https://doi.org/10.1111/j.1939-1676.2012.01013.x.

15. Morais LK, Machado FME, Alberto H, Coelho HE. Macro and microscopic study of pancreas in dogs. PUBVET [Internet]. 2014 [cited 2021 Apr 10];8(2):84-229. Available from: http://www.pubvet.com.br/artigo/297/estudo-macro-e-microscopico-de-pancreasem-caes

Sousa FG, Mendes ACR. Canine pancreatitis: The development of the pancreatic inflammatory condition and the clinical-therapeutic approach. Vet. e Zootec. 2021; v28: 001-011. 
16. French JM, Twedt DC, Rao S, Marolf AJ. Computed tomographic angiography and ultrasonography in the diagnosis and evaluation of acute pancreatitis in dogs. J Vet Intern Med. 2019;33(1):79-88. doi: https://doi.org/10.1111/jvim.15364.

17. Kuzi S, Mazor R, Segev G, Nivy R, Mazaki-Tovi M, Chen H, et al. Prognostic markers and assessment of a previously published clinical severity index in 109 hospitalised dogs with acute presentation of pancreatitis. Vet Rec. 2019;187(2):e13. doi: https://doi.org/10.1136/vr.105364.

18. Cridge H, Sullivant AM, Wills RW, Lee AM. Association between abdominal ultrasound findings, the specific canine pancreatic lipase assay, clinical severity indices, and clinical diagnosis in dogs with pancreatitis. J Vet Intern Med. 2020;34:636-43. doi: https://doi.org/10.1111/jvim.15693.

19. Kealy JK, McAllister H, Graham JP. Radiologia e ultrassonografia do cão e do gato. 5a ed. Rio de Janeiro: Elselvier; 2012.

20. Gardner TB, Vege SS, Pearson RK, Chari ST. Fluid resuscitation in acute pancreatitis. Clin Gastroenterol Hepatol. 2008;6(10):1070-6. doi: https://doi.org/10.1016/j.cgh.2008.05.005.

21. Bhoomagoud M, Jung T, Atladottir J, Kolodecik TR, Shugrue C, Chaudhuri A, et al. Reducing extracellular $\mathrm{pH}$ sensitizes the acinar cell to secretagogue-induced pancreatitis responses in rats. Gastoenterology. 2009;137(3):1083-92. doi: https://doi.org/10.1053/j.gastro.2009.05.041.

22. Wu BU, Hwang JQ, Gardner TH, Repas K, Delee R, Yu S, et al. Lactated ringer's solution reduces systemic inflammation compared with saline in patients with acute pancreatitis. Clin Gastroenterol Hepatol. 2011;9(8):710-7. doi: https://doi.org/10.1016/j.cgh.2011.04.026.

23. Weatherton LK, Streeter EM. Evaluation of fresh frozen plasma administration in dogs with pancreatitis: 77 cases (1995-2005). J Vet Emerg Crit Care. 2009;19(6):617-22. doi: https://doi.org/10.1111/j.1476-4431.2009.00483.x.

24. Zanoni FL. Estudo dos efeitos da solução salina hipertônica e do Ringer lactato sobre a resposta da microcirculação mesentérica e a translocação bacteriana em modelo de obstrução intestinal e isquemia em ratos [dissertação]. São Paulo: Universidade de São Paulo-USP; 2010.

25. Karanjia ND, Lutrin FJ, Chang YB, Reber HA. Low dose dopamine protects against hemorrhagic pancreatitis in cats. J Surg Res. 1990;48(5):440-3. doi: https://doi.org/10.1016/0022-4804(90)90009-q.

26. Rau SE, Barber LG, Burgess KE. Efficacy of maropitant in the prevention of delayed vomiting associated with administration of doxorubicin to dogs. $\mathrm{J}$ Vet Intern Med. 2010;24(6):1452-7. doi: https://doi.org/10.1111/j.1939-1676.2010.0611.x. 
27. Marks SL, Kook PH, Papich MG, Tolbert MK, Willard MD. ACVIM consensus statement: support for rational administration of gastrointestinal protectants to dogs and cats. J Vet Intern Med. 2018;32(6):1-18. doi: https://doi.org/10.1111/jvim.15337.

28. Williams DA. Diagnosis and management of pancreatitis. J Small Anim Pract. 1994;35(9):445-54. doi: https://doi.org/10.1111/j.1748-5827.1994.tb03945.x.

29. Sun W, Watanabe Y, Toki A, Wang Z. Beneficial effects of hydrocortisone in induced acute pancreatitis of rats. Chin Med J (Engl) [Internet]. 2007 [cited 2021 Apr 10];120(20):1757-61. Available from: https://pubmed.ncbi.nlm.nih.gov/18028766/

30. Niederau C, Niederau M, Luthen R, Strohmeyer G, Ferrell LD, Grendell JH. Pancreatic exocrine secretion in acute experimental pancreatitis. Gastroenterology. 1990;99(4):1120-7. doi: https://doi.org/10.1016/0016-5085(90)90633-c.

31. Flint RS, Windsor JA. The role of the intestine in the pathophysiology and management of severe acute pancreatitis. World J Gastroenterol. 2003;5(2):69-85. doi: 10.1080/13651820310001108.

32. Kotani J, Usami M, Nomura H, Iso A, Kasahara H, Kuroda Y, et al. Enteral nutrition prevents bacterial translocation but does not improve survival during acute pancreatitis. Arch Surg. 1999;134(3):287-92. doi: https://doi.org/10.1001/archsurg.134.3.287.

33. Qin HL, Su ZD, Hu LG, Ding ZX, Lin Q-T. Effect of early intrajejunal nutrition on pancreatic pathological features and gut barrier function in dogs with acute pancreatitis. Clin Nutr. 2002;21(6):469-73. doi: https://doi.org/10.1054/clnu.2002.0574.

34. Qin HL, Su ZD, Gao Q, Lin Q-T. Early intrajejunal nutrition: bacterial translocation and gut barrier function of severe acute pancreatitis in dogs. Hepatobiliary Pancreat Dis Int [Internet]. 2002 [cited 2021 Apr 10];1(1):150-4. Available from: https://pubmed.ncbi.nlm.nih.gov/14607647/

35. Qin HL, Su ZD, Hu LG, Ding Z-X, Lin Q-T. Parenteral versus early intrajejunal nutrition: effect on pancreatitc natural course, entero-hormones release and its efficacy on dogs with acute pancreatitis. World J Gastroenterol. 2003;9(10):2270-3. doi: https://doi.org/10.3748/wjg.v9.i10.2270.

36. Qin HL, Su ZD, Hu LG, Ding Z-X, Lin Q-T. Effect of parenteral and early intrajejunal nutrition on pancreatic digestive enzyme synthesis, storage and discharge in dog models of acute pancreatitis. World J Gastroenterol. 2007;13(7):1123-8. doi: https://doi.org/10.3748/wjg.v13.i7.1123.

Recebido em: 26/05/2021 Aceito em: 28/07/2021 